\title{
Integrating Social Power and Political Influence into Models of Social-Ecological Systems
}

\author{
Damon M. Hall ${ }^{1}$, Todd M. Swannack ${ }^{2}$, Eli D. Lazarus ${ }^{3}$, Markus J. Peterson ${ }^{4}$, \\ Susan J. Gilbertz ${ }^{5}$, Cristi C. Horton ${ }^{6}$, Tarla Rai Peterson ${ }^{7}$
}

\begin{abstract}
Shaping policy for environmental sustainability depends upon decision-makers conceptualizing problems in ways that are either shared or similar enough to communicate about, diagnose, and act. The quality of this shared mental model of a social-ecological system (SES) is paramount to its effectiveness. Fundamentally, the mental model must integrate multiple kinds of knowledge about the system. If the decision-making body's assumptions about, description of, and solution for a problem do not to reflect the many ways stakeholders know a system, then the products of that decision-making process are viewed as illegitimate. Sustainability policy must fit the often subtle social order of the communities expected to implement it. In this essay, we discuss how a systemsbased perspective can be a versatile tool for tackling these challenges of knowledge integration and decision-making in the context of a complex SES. Using social theory of Pierre Bourdieu, we construct a conceptual model that illustrates a route for integrating locally known social complexities (power, influence) gleaned from stakeholder interviews $(\mathrm{N}=57)$. Stakeholders and end-user groups may dismiss any model that they perceive fails to satisfactorily account for specific, locally salient social nuances. Our approach leverages the overlapping notion of "capital" in social and ecological theory to demonstrate how reciprocal interactions between human and ecological systems can be adopted into tools for reaching viable solutions to SES problems.
\end{abstract}

Keywords: Sustainability science, Social capital, Power, Boundary object, Water resources management, Floodplain development, Riparian ecology

\section{Introduction: Integrating Different Ways of Knowing}

One of the challenges for transdisciplinary sustainability-science research is to integrate different kinds of knowledge into usable forms relevant to the diverse audiences tasked with addressing sustainability problems. Bringing scientific, technical, experienced, and tacit views of a system into alignment with each other is critical for developing a shared body of assumptions from which to make decisions. Shared conceptualizations of a system must be salient, legitimate, and credible to all parties' perspectives involved in planning if those policies made are to satisfy the persons expected to implement them (Clark et al., 2011). This task moves past multidisciplinary and interdisciplinary efforts at social and biophysical science collaboration. Combining scientific and lay knowledge into an accessible-and politically acceptablerepresentation of a system that then becomes a tool for deliberating about environmental problems and making decisions requires treating local social and political complexities with the

${ }^{1}$ Center for Sustainability, Saint Louis University, Des Peres Hall, Suite 203E, 3694 West Pine Mall, Saint Louis, MO 63108 USA

${ }^{2}$ US Army Engineer Research and Development Center, Environmental Laboratory, Vicksburg, MS, USA

${ }^{3}$ Environmental Dynamics Lab, School of Earth and Ocean Sciences, Cardiff University, Cardiff, UK

${ }^{4}$ Department of Wildlife and Fisheries Sciences, Texas A\&M University, College Station, TX, USA

${ }^{5}$ Department of Social Sciences \& Cultural Studies, Montana State University-Billings, Billings, MT, USA

${ }^{6}$ Department of Fine Arts and Communications, Tarleton State University, Stephenville, TX, USA

${ }^{7}$ Department of Wildlife and Fisheries Sciences, Texas A\&M University, College Station, TX, USA

Swedish University of Agricultural Sciences. 
same quality of attention typically afforded to the biophysical components.

One way in which to explore transdisciplinary knowledge integration is through "boundary objects", a category of shared tools for deliberation. Boundary objects are collaborative products - maps, reports, decision tools, forecasts, models, others - created by various actors that are adaptable to different viewpoints and yet robust enough to be meaningful to each group's adherents (Cash et al., 2003; Clark et al., 2011; Star \& Griesemer, 1989). Boundary objects are useful ways of representing constituent knowledge relevant to all interested parties. By pursuing strategically the interests of all parties, boundary objects project authority. Ultimately, the purpose of these intermediary tools is to facilitate relationships between science, society, and decisionmaking that lead to more productive policy making (Jasanoff, 1990).

\subsection{Models as Boundary Objects}

When systems models - conceptual or mathematical models of social-ecological systems designed for prediction or explanation (cf. Hall, Lazarus, \& Swannack, 2014)—are constructed utilizing the expertise of many, they can serve as a boundary object that bridge seemingly disparate forms of knowledge. Models can be powerful tools for decision making with lasting implications upon social order. They can capture the dynamics of various realities' and their moving parts simultaneously. Models can represent integrated interdisciplinary science (Grant, 1998; Heemskerk, Wilson, \& Pavao-Zuckerman, 2003; van der Leeuw, 2004). Furthermore, scholars are increasingly incorporating lay characterizations of resource systems into models of human-environment dynamics (Cash, Borck, \& Patt, 2006; Clark, 2007; Kates, 2011; Kates et al., 2001; Pohl, 2011; Schmolke, Thorbek, DeAngelis, \& Grimm, 2010; Talwar, Wiek, \& Robinson, 2011).

As representations of reality, models can provide means of orientation within a problem space and shape the basis for decision making. Models are sometimes compared to maps (Robinson, 1991) that chart a course through a conceptual landscape, unfamiliar or familiar. Models have been compared to narratives (Allen, Zellmer, \& Wuennenbeg, 2005) capable of making sense of complexity via a coherent, temporally structured, internally consistent, familiar, and pleasing form of story told to a specific audience. Models also have been compared to landscape paintings (Dietrich, Bellugi, Sklar, \& Stock, 2003) where varying forms of realism reflect various realities. In these metaphors and in others, the power of a model is in its appeal to multiple or diverse audience as a way to lend transparency to an otherwise opaque or occluded technical idea, concept, construction, description, or argument.

Essentially, models are tools for communication (Hall et al., 2014), and the process of creating a model forces the model builders to enunciate clearly their held assumptions (Krebs, 2005; Voinov, Seppelt, Reis, Nabel, \& Shokravi, 2014). An effective model can illuminate, demonstrate, and articulate relationships among disparate parts of a system with a degree of precision not afforded by language alone (van der Leeuw, 2011). Models thus offer a means of communicating about complexity. Inescapable, then is the fact that the very act of communicating the rationale, concept, results, implications, and limitations of a model influences how the model is used and perceived (Hall et al., 2014).

\subsection{A Critique of Models}

Models have been criticized for providing only the selective view of reality that is convenient for the modeling process; as a result, socio-political and cultural dynamics that are especially challenging to capture and render in abstraction may be glossed over in favor of more manageable representations (Crane, 2010; Lucie, Gauvin, \& Raine, 2011). For example, models of coupled human-natural systems typically treat their embedded social components with less sophistication than their physics-based ecological ones (Burke, Joseph, Pasick, \& Barker, 2009). 
What results are idealized, sanitized, and apolitical views of reality for the convenience of science that have no bearing on the policy decisions (Latour, 2005; Paolisso, 2009; Peterson, Peterson, \& Peterson, 2005). Managing shared natural resources are social and political activities that involve considerations of who has the right to use the resource as well as determining behavioral targets of policy, including prohibited activities (cf. Ascough II, Maier, Ravalico, \& Strudley, 2008; Dryzek, 1997; Kemmis, 1990; Odum, 2007).

Policy reflects and shapes the social order. While scientific expertise can provide high quality technical information to managers, local decision-making cultures still retain authority under existing power dynamics that can inhibit sustainable policy efforts (Peterson, et al., 2005). Despite an acknowledgement of the importance of power relationships within natural resource planning, "little empirical attention has been paid to exploring the workings of power in the field" (Courtois \& Tazdaï, 2007; Raik, Wilson, \& Decker, 2008, p. 730; Robbins, 2012). If models of socialecological systems are to improve the productivity of sustainability policy making, they must satisfy multiple audiences' perspectives of reality by incorporating familiar dynamics of social power. This means giving greater attention to the complexities of social groups, human behaviors, and decision-making processes.

\subsection{Integrating Social Power and Political Influence}

In this essay, we seek to address the challenges of incorporating social-system dynamics into coupled human-natural system modeling by providing an example of a conceptual model of social complexity in a natural-resource system. Specifically, we seek to integrate notions of social power and political influence into a form amenable to mathematical systems modeling. To accomplish this, we use sociologist Pierre Bourdieu's (1985; 1986; 1989; 1990; 1993) theory of social capital to fashion a common language between natural and social capital. We model naturalresource management decision making regarding the cumulative impacts of social and ecological responses to various management options regarding floodplain development. To provide sitespecific data for illustrating how this model would operate, we use qualitative ethnographic interview data gathered through a cultural inventory of the Yellowstone River (Montana, USA) (cf. Gilbertz, Horton, \& Hall, 2007; Gilbertz, Austin, Norton, Horton, \& Hall, 2011; Hall, 2006; Hall, Gilbertz, Horton, \& Peterson, 2012). The conceptual model demonstrates the integration of qualitative social data into a mathematical ecological systems model that addresses the influence and dynamics of social power within rural riverfront communities in Montana.

The multi-agent simulation model we offer here is designed to advance the discussion of how structures of social power could influence a coupled systems model. This conceptual model illustrates that careful examination of social influence can be integrated into modeling efforts to appropriately account for the complexity of coupled natural-human systems. This can lead to more socially robust models (Gibbons, 1999; 2000) that are more legitimate to communities as well as to the improvement of group-based modeling processes (mediated modeling, co-modeling, companion modeling, participatory modeling, etc.) (Hall et al., 2014; Levrel, Etienne, Kerbiriou, Le Page, \& Rouan, 2009; van den Belt, 2004; Voinov \& Bousquet, 2010).

First, we describe the socio-political dynamics of the Upper Yellowstone River that comprise the planning exigencies and source data for this project. Next, we describe Bourdieu's theory of capitals and how we have adapted its use for modeling social power within the decision setting. Then we describe specifically how we move these notions into a conceptual model. We end with a discussion of project implications that we hope contributes to the broader challenge of balancing otherwise imbalanced levels of detail in modeled social and ecological representations of coupled-systems problems in order to make more salient, legitimate, and credible models for collaborative decision making in sustainability contexts. 


\section{Case: Riverfront Development along the Yellowstone River}

The conceptual model presented here responds to a management dilemma faced by US federal, state and local organizations with interests in development and responsibilities for natural-resource management. The specific context in this case focuses on riparian setback ordinances (streamside buffer management zones) that regulate floodplain development along the Yellowstone River. The jurisdictional scale selected is Park County, Montana. We selected Park County because (1) the county level is the most typical scale for decisions made concerning zoning decisions in Montana, (2) this socio-economically diverse community routinely engages in decision making concerning riverfront development and (3) the upstream section of the river exhibits development trends similar to those increasingly common in downstream communities (Chapple, 1997; Gilbertz et al., 2007). Decision-making scenarios in Park County thus serve as a representative exemplar for events likely to affect other, downstream communities along the Yellowstone River.

We use a subset of the socio-economic data collected from the Yellowstone River Cultural Inventory (YRCI) (Gilbertz et al., 2007; Hall et al., 2012) to simulate stakeholder decision-making dynamics among three dominant stakeholder populations: agricultural landowners, investment landowners, and recreational outfitters. The subset $(N=57$, equal to approximately $1 / 5$ of the total sample size) of the YRCI is used to delimit the study to Park. Using a subset also enables future verification studies.

The 2006 YRCI was a large-sample naturalistic field study (Lincoln \& Guba, 1985) consisting of in-depth ethnographic interviews with 313 Yellowstone River landowners, agriculturalists, civic managers, and recreationalists across 540 river miles (cf. Gilbertz et al., 2007; Hall et al. 2012). The study constituted the social-cultural dimensions of a larger ten-year \$10 million USD cumulative-effects study on the Yellowstone River funded by the US Army Corps of Engineers. The YRCI aimed to understand (1) how riverfront stakeholders conceptualized river management practices, (2) the ecological properties of the river including how they valued the riparian area and (3) how informants thought riverfront land-use conflicts should be managed. Interviews were conducted face-to-face, using open-ended questions as a means of encouraging residents to talk about the river, the local environs, and their personal observations and concerns freely and in their own words.

The Yellowstone River catchment is large relative to other catchments in the American West. The river basin drains an area over $181,000 \mathrm{~km}^{2}\left(70,000 \mathrm{mi}^{2}\right)$ from its headwaters above Yellowstone National Park to the confluence with the Missouri River in North Dakota. The Yellowstone River also is the United States' longest undammed river. The natural features of the river make riverfront lands desirable to agriculturalists, recreationalists, and real-estate investors. The large volume of water discharged by the river affords high agricultural productivity; its waters are used for irrigation in an otherwise arid landscape with an average annual rainfall of $38 \mathrm{~cm}$ (14.8 in). The free-flowing character of the river creates biological and scenic amenities attractive to recreational users. The cold-water riparian habitat supports a wild trout population earning the designation of a Blue Ribbon Trout Stream (Leighton, 1998) including the endangered cutthroat trout (Oncorbynchus clarki bouvieri). As notoriety of the fishery and related river recreation has spread in recent decades, increasing numbers of people have bought property and built homes near the river (Hall, Gilbertz, Horton, \& Peterson, 2013). The scenic and recreational opportunities continue to attract visitors, retirees, and vacationers as the fastest growing economic sector in Park County. As a result, riverfront development within the 100-year floodplain has increased throughout rural stretches of the river. From 1980 to 2000 the number of structures within Park County's floodplain increased from 379 to 594 buildings; a 57\% increase (BBC Consulting, 2002; Tempting Fate, Greater Yellowstone Coalition, 2002). Large portions of the valley floodplain were 
converted from riparian vegetation to lawns, homes, and impervious surfaces.

Because the riparian area is limited, all land-use interests must compete. Competing desires for the river's characteristics are further constrained by its undammed character, which causes seasonal flooding due to melting mountain snowpack each June. These high-volume flows alter the river's channel by erode streambanks, impacting productive agricultural lands, residential properties, and public infrastructure.

\subsection{The Politics of Flood Control}

There are two ways to mitigate the risks and damages from this flooding. The most common way for property owners to mitigate against erosion and overbank flooding is through the use of in-stream and streambank stabilization structures such as rip-rap-boulders placed along the banks to deflect the velocity of floodwaters. The U.S. Army Corps of Engineers (USACE) in conjunction with state agencies (Montana Department of Environmental Quality), county conservation districts and county floodplain administrators regulate bank-stabilization projects through permits under the authority of Section 10 of the Rivers and Harbors Act of 1899 (33 U.S.C. S 401) and Section 404 of the Federal Water Pollution Control Act: the Clean Water Act (CWA; 33 U.S.C. \ 1344). The permitted deployment of structures to protect high-risk properties restricts and diverts stream flow, which inhibits normal water-storage functions of the riparian vegetation. Such diversion also changes the riparian system by increasing flow velocity at other banks, thereby intensifying downstream flooding and erosion and inadvertently affecting other biophysical changes. Long-term geomorphologic and biological impacts include channelization of the river which disrupts natural flood control, narrowing floodplains which exacerbate soil recharge, native vegetation and riparian forest regeneration, the downstream spread of exotic (invasive) vegetation, aquatic and terrestrial habitat suitability, and other downstream erosion (cf. Ellis \& Richard, 2008; Naiman \& Decamps, 1997; Ward, Tockner, \& Schiemer, 1999).

The second and less common means of dealing with flood risk is through riverfront zoning restrictions. Zoning decisions occur at the county and local community levels. These land-use planning policies regulate development along the river and within the 500-year floodplain beyond minimum standards required for participation within the U.S.'s Federal Emergency management Agency's (FEMA) National Flood Insurance Program (NFIP) which Park County joined in 1987. The current riparian setback ordinance limits development within 150 feet $(\sim 46 \mathrm{~m})$ of the river's high-water mark in order to qualify for the NFIP (Hazard Mitigation Plan, 2005). These local zoning decisions impact riparian habitat, floodplain functioning, and, as a result, affect the severity and frequency of flooding. For this undammed river, as its channel migrates, so too do the risks of flooding (Thatcher, et al., 2009).

Increasing awareness of short- and long-term impacts of riverfront residential development has led to increased interest in zoning ordinances and floodplain planning (cf. Hazard Mitigation Plan, 2005). For years, landowners have cited political and economic rationales such as private property rights for thwarting any attempts at regulating riverfront zoning law. This enabled them to subdivide, develop, and otherwise use the lands within the riparian corridor to their immediate advantage. Citizens frequently voice concern about the rate of development within the floodplain, yet a strong private-property rights ethos in the region often prevents zoning efforts (Peterson and Liu, 2008).

As more homes are built along the river, flooding prompts more homeowners to install bank stabilization projects. For example, in 1996 and 1997, two consecutive 100-year floods caused damages of \$1.6 million USD in 1996 and \$750k USD in 1997 (in 2005 USD; Hazard Mitigation Plan, 2005), and a record number of bank stabilization permits were applied for and granted (Auble et al., 2004). Recreationalists became concerned about the impacts of these bank altering 
projects upon the fishery and the aesthetic qualities of the river. Fears over these impacts prompted the National Geographic to call the Yellowstone "America's last best river" and the American Rivers NGO placed the Yellowstone on its Top ten List of Endangered Rivers in 1999 (Chapple, 1997) and again in 2005 due to the increased rate of development within the 100-year floodplain (DeVries, 2006).

In November of 1997, Montana's Governor became concerned about the adverse impacts of increased floodplain development and bank stabilization projects upon the river's tourism industry. He initiated the Governor's Upper Yellowstone River Task Force to involve publics in research that would encourage a more comprehensive and consolidated planning effort (Task Force Final Report, 2003). Additionally, a collaboration of recreational and environmental organizations filed a successful lawsuit requiring the USACE to examine the cumulative effects of bank stabilization upon riparian habitat (Montana Council of Trout Unlimited $v$. Corps of Engineers). A moratorium was placed on new bank stabilization projects in 2001, but no additional zoning setbacks to control riverfront development have been enacted despite unsuccessful efforts to pass county-level policies in 2004, 2006, and 2008 (Nolt, 2007) and at the state-level Big Sky Rivers Act (MT HB-455) in 2009 (Lowery, 2009).

\section{Adaptation of Pierre Bourdieu's Theory of Capital}

Sociologist Pierre Bourdieu's theory of symbolic capital provides a potentially useful approach for understanding the Yellowstone's socio-political relationships among advocates of competing interests, norms, and social processes, and the ways in which those relationships are entwined in the fluvial and ecological dynamics of the river itself.

In formal terms, capital is the human capacity to act upon a system based on relative position in the social and ecological logics of a situation. Bourdieu's (1985, 1986, 1989, 1990, \& 1993) theory of capital addresses how capital accumulation enables participants to influence social systems. Bourdieu represents the social world as a self-producing field of hierarchies where agents compete for material and symbolic resources. This competition organizes the positions of the persons within it. Such relations are so familiar that agents often fail to recognize how thoroughly they are embedded in practices that reinforce existing positions of power (Bourdieu, 1989).

Bourdieu describes society as a game (1993) where capital refers to the resources that provide players with social power with which to play. Key to this argument, is the expansion of the treatment of capital beyond economics to include social (affiliative) and cultural resources (1989). The amount of aggregate capital and the hierarchical arrangement of types of capital in a particular social order influence an agent's position and capacity for playing the game (1985).

Following Bourdieu (1986, 1990), we identify three sub-types of capital that combine to create a player's total symbolic capital. Economic capital refers to financial resources, such as money and property; affiliative capital refers to resources of affiliation, social connectivity, and networking capacities that are central to negotiating social norms; and cultural capital refers to resources of prestige that are embodied, objectified, and institutionalized in educational credentials, aesthetic preferences, general cultural awareness, and verbal facility. All three combine to create social capital, or the relative weight and composition of an individual's legitimate power and social credibility within a location.

\section{Model Description}

An explicit modeling of influence and power in social systems may enable managers and planners to visualize the potential impacts on ecological systems and decision-making. The model we describe here accounts for vested individuals and social power within decision-making groups 
and how their decisions interact with riparian ecology as the principal form of natural capital in this system. The material transferred within this model is capital in both social and natural forms. The model consists of four nested and interactive sub-models: (1) three individual stakeholder populations and their total accumulation of three forms of capital described above; (2) the decision-making process concerning riverfront development zoning restrictions; (3) the natural capital of the functioning riparian floodplain; and (4) the frequency and severity of stochastic flood events. The social and natural capitals affect, and are affected by, the decision-making process of setback policies and setback outcome. The severity of flooding acts as a catalyst for initiating the decision-making process.

\subsection{Stakeholder Capital}

The model includes three stakeholder populations to simulate the setback decisionmaking process. These stakeholders are riverfront real estate investment landowners (Inv), agricultural landowners (Agr), and recreationalists with outdoor experience-based business interests $(R e c)$. Each stakeholder group has a unique magnitude of influence represented by their total accumulation of social capital. This total social capital (CapTot) consists of a combination of (1) economic capital (Econ), (2) affiliative capital (Aff), and (3) cultural capital (Cul).

The economic capital values of each stakeholder group refer to income and financial assets owned. The affiliative capital values are derived from the number of social organizations and networks to which an individual belongs. It represents the stakeholder group's embeddedness in social and political structures. Cultural capital is both embodied and institutionalized. Embodied cultural capital is derived from the number of generations one's family has owned land in the county; it represents rootedness in the community, accumulates with successive generations and cannot be stripped from a person. Institutionalized cultural capital derives from educational credentials denoting expertise, such as certifications or academic degrees (Bourdieu, 1986).

The numbers used to represent stakeholder groups' cumulative capital, the relative weighting between the forms of capital, and the rates of capital gains and losses are derived from field observations, in-depth interviews, local advisors, and U.S. Census Bureau data. Based on our field observations and analysis from the YRCI, these three forms of capital are consistently regarded among Park County participants as measures of influence within community decision making groups. The forms of capital exist in a hierarchy with relative weighting (Rel Eco, Rel Cul, and Rel Aff) (Table 1).

Table 1. Relative weights of the influence of each sub-type of capital

\begin{tabular}{cc}
\hline Types of Capital & Relative Weight \\
\hline Cultural & 0.40 \\
Economic & 0.30 \\
Affiliative & 0.30
\end{tabular}

For the setting in Park County, we weighted each form of capital according to the relative influence based on 57 interviews (14 agriculturalists, 16 recreationalists, 27 other riverfront landowners and managers). Persons consistently given the most deference within the community are those whose families "homesteaded" the land they currently own (US Homestead Acts of 1862 \& 1909). Therefore, for these agents, cultural capital is given more weight $(\mathrm{Cul}=0.40)$ relative to economic and affiliative capital (Econ 0.30; Aff = 0.30). In Park County, having money is slightly more important than having a dense interpersonal network of social ties. The relative weighting of the types of social capital can be adjusted depending upon the context. The total sum of all three forms of capital for all stakeholders who comprise a group is taken as that stakeholder population's total capital (CapTot), and reflects their collective influence within the decision-making process. The maximum amount of capital accumulation for each type of capital 
is represented on a 1-100 unit scale. The maximum total capital accumulation from the three forms of capital that a group can have is 300. Each stakeholder group's initial CapTot scores are listed in Table 2. The maximum amount of capital operating in the society is denoted as CapTot Society.

Table 2. Initial capitals of stakeholder populations

\begin{tabular}{cccccc}
\hline Stakeholder Group & $\begin{array}{c}\text { Economic } \\
\text { Capital }\end{array}$ & $\begin{array}{c}\text { Affiliative } \\
\text { Capital }\end{array}$ & & $\begin{array}{c}\text { Cultural } \\
\text { Capital: Heritage }\end{array}$ & $\frac{\text { Total Capital }}{\text { (Baseline) }}$ \\
\hline Investment Landowner & 100 & 100 & 25 & 225 \\
Recreationalist Outfitter & 50 & 100 & 50 & 200 \\
Agricultural Landowner & 75 & 75 & 75 & 225 \\
\hline
\end{tabular}

\subsection{Population of stakeholder decision makers}

Each population is represented as a sub-model showing the three forms of capital $(\mathrm{Cul}$, Eco, Aff), their population (Num), with a specific setback policy preference (Pref) expressed in feet from the river. These interests and forms of capital affect and are affected by the other submodels of capital accumulation (e.g., floodplain functioning) and the decision-making process.

To account for the shifting numbers of decision-making stakeholders in this system over time that will impact the decision calculus, each stakeholder category is represented as a population (i.e., NumRes, NumAgr, etc.). These numbers are derived from U.S. Census Bureau economic data and USDA Principal Farm Operator census data for Park County, MT (Table 3), and adjusted by emigration (Em) and immigration (Imm) rates based on US census records. To account for only those agricultural stakeholders along the river, the USDA Principal Farm Operator census figures were adjusted using a 2003 GIS study that found that approximately $12 \%$ of all Park County rural land parcels (Montana Natural Resource Information System) occurred within 600 feet of the existing 100-year floodplain using (American Rivers and Greater Yellowstone Coalition, 2003). The 2003 study excludes parcels within the city limits of Livingston, MT, as the city's flood management program manages development within its floodplain.

Table 3. Index for stakeholder population ratios in Park County, MT NAICS number of employees of March 12 per year

\begin{tabular}{lccccccccc}
\hline$\underline{\text { Stakeholder Industry }}$ & $\underline{1998}$ & $\underline{1999}$ & $\underline{2000}$ & $\underline{2001}$ & $\underline{2002}$ & $\underline{2003}$ & $\underline{2004}$ & $\underline{2005}$ & $\underline{2006}$ \\
\hline Agricultural (a) & 82 & 85 & 80 & 76 & 73 & 82 & 81 & $82^{*}$ & $83^{*}$ \\
Investment Landowner (b) & 37 & $20-99 *$ & 43 & 38 & 44 & 58 & 48 & 49 & $20-99^{*}$ \\
Recreationalist Outfitter (c) & 100 & 73 & 78 & 79 & 105 & 106 & 138 & 114 & 121 \\
\hline
\end{tabular}

Shading indicates years with complete data.

(a) USDA principal farm operator Census x .12 (1997, 2002, 2007 figures) + [11] Forestry, fishing, hunting, and agriculture support. (b) [53] Real estate \& rental \& leasing. (c) [71] Arts, entertainment \& recreation. (d) Non Ag parcels from 2003 (750) indexed to US Census 2003 $(15859)=(0.047281759) \times$ US Census figures from 2000 and 2005. $\left(^{*}\right)$ US Census estimate.

\subsection{Decision-making Process}

The three stakeholder populations' capital sub-models meet in the decision-making submodel to determine revisions to county floodplain buffer-zone ordinance. The policy in discussion dictates how far from the riverbank new development-new buildings, improvements to buildings, grading, filling, and other human-caused changes to the land-should be set back from the high water mark of the streambank (Hazard Mitigation Plan, 2005). The current Park County riparian setback ordinance is 150 feet $(\sim 46 \mathrm{~m})$ (Ellis and Richard, 2008). Each group has a preferred setback distance (SetPref) that will increase their economic and affiliative capital (Table 
4).

Management $(M g m t)$ holds primary decision authority. However, resource management agencies can be over-ruled by significant social pressure, such as lawsuits, when management agencies lose public support. Management objectives (Pref Mgmt) are established to ensure that there is a certain amount of riparian area (Mgmt Max Nat) and considers setback decision making upon this preferred amount of functioning riparian area.

Table 4. Stakeholder group's setback preferences and affected capitals

\begin{tabular}{|c|c|c|c|c|c|}
\hline$\frac{\text { Stakeholder }}{\text { Group }}$ & $\begin{array}{l}\frac{\text { Current }}{\text { Setback }} \\
\text { (in Feet) }\end{array}$ & $\begin{array}{c}\frac{\text { Setback }}{\text { Preference }} \\
\text { (in Feet) }\end{array}$ & Setback Preference & $\begin{array}{l}\underline{\text { Setback }} \\
\text { Decision } \\
\text { Impacts: }\end{array}$ & 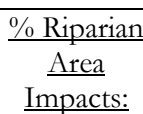 \\
\hline $\begin{array}{l}\text { Investment } \\
\text { Landowners }\end{array}$ & 150 & 0 & $\begin{array}{l}\text { No restrictions: Allows for maximum property } \\
\text { value for resale and subdivision }\end{array}$ & Aff, Econ & \\
\hline $\begin{array}{l}\text { Recreational } \\
\text { Outfitters }\end{array}$ & 150 & 500 & $\begin{array}{l}\text { Restore quality of resource to improve quality } \\
\text { of recreational experience; Increase business } \\
\text { due to natural amenities of river; Protect } \\
\text { valuable wildlife species and habitat }\end{array}$ & Aff, Econ & Econ \\
\hline $\begin{array}{l}\text { Agricultural } \\
\text { Landowners }\end{array}$ & 150 & 100 & $\begin{array}{l}\text { No change in restrictions: Allows for } \\
\text { maximum property value for resale and } \\
\text { subdivision; Adheres to a common ethos of } \\
\text { "private property rights" protection; } \\
\text { Desire increased quality of riverfront livestock } \\
\text { forage; and less need for exotic species } \\
\text { management and associated expenses }\end{array}$ & Aff, Econ & Econ \\
\hline
\end{tabular}

The stakeholder group with the highest total accumulated capital will likely influence (Social Pressure) the setback decision based on his/her preference (winner). However, a stochastic corrective (ran) is built into this decision-making function which accounts for extenuating external factors, events, and circumstances that may affect the power balances in the decision-making landscape.

Stakeholder groups can pool their capital in coalitions (coal). If a coalition can reach a certain politically-relevant threshold (CapTotCoalPlus $>$ Social Pressure Threshold) — such as using affiliative capital to mobilize social networks to successfully initiate and pass a ballot referendum-then the coalition exerts social pressure for their preferred setback policy. If they pool their capital and do not meet the social pressure threshold then they cannot exercise social pressure upon the decision making as a coalition.

\subsection{Time Scale}

While the time step for the simulation is yearly, decisions concerning the streamside buffer management on the Yellowstone River occur irregularly. Decisions are often prompted when a confluence of social, political, and environmental factors exert pressure on Mgmt agencies. For example, riparian planning has been precipitated by changes in resource law and bureaucratic structures (1974 Clean Water Act), significantly severe seasonal flood events (Governor's Task Force in 1997 following two 100-year floods of 1996 and 1997), changes in political personalities and demographics (election cycle of 2012), etc. Therefore decision making is not tied to any periodicity but is relative to particular flood events - typically in June-severe enough for local community members to decide policy changes are necessary.

\subsection{Natural capital: Native riparian vegetation}

We represent natural capital as the percent of unaffected riparian floodplain, which is based on the percent of unmodified stream bank which allows for normal channel migration and 
riparian floodplain function (Thatcher et al., 2009). The amount of unaltered floodplain is viewed as an indicator of ecosystem stability with regards to mitigating flood damage (Mitsch and Gosselink, 2007). As the amount of floodplain in a riparian system decreases-through decreasing setback requirements-flood damage increases in severity due to the loss of flood water storage functioning of riparian vegetation. Increasing amounts of floodplain area leads to increased capacity of vegetation to store flood overbank waters (Mitsch and Gosselink, 2007).

Riparian area changes as a result of increasing or decreasing Setback zoning decisions, namely, a larger setback increased riparian floodplain area and a smaller setback decreased it. We assumed setback decisions affect the functioning of the riparian area within the 100-year floodplain on a sigmoid growth curve: $0 \mathrm{ft}$ of setback $=0 \%$ functional riparian area; $150 \mathrm{ft}$ setback $=80 \%$ functional riparian area; $500 \mathrm{ft}$ setback $=100 \%$ functional riparian area.

\subsection{Flooding}

The most significant variables acting as catalysts for stakeholder populations to initiate the decision making are (1) the frequency of flood events (Flood Freq) and (2) the severity of flood events (Flood Severity). Flood events are generated stochastically, and the type of flood (i.e., 1, 5, $25,50,100$, or 500-year flood) is based on historic flood occurrences for the region (Hazard Mitigation Plan, 2005). Flood frequency is calculated as the number of flood events occurring in subsequent years. We assumed flood severity was a function of the type of flood as well as the percent of riparian area remaining. Due to the large amount of uncertainty associated with the relationship between flood damage and percent riparian floodplain, we represented the relationship between flood percent riparian area remaining and flood damage as an index (RAI) and performed an extensive calibration on this parameter, altering both the magnitude and functional form of the relationship.

\subsection{Feedback: natural capital to social capital}

Flood severity and flood frequency are the catalysts for setback decision-making. The investment landowners' (Inv) setback preference is not driven by the risk of flooding. Their capitals are affected by flooding only to the degree that flood severity influences the capacity to develop floodplain properties. Therefore, groups of investment landowners will advocate for less setback or exhibit neutrality if there is frequent or severe flooding. The recreationalists' (Rec) setback preference is as large as possible, because more riparian area increases recreational opportunities and the quality of experience, thus increasing the recreationalist's total capital. Recreationalists use frequent and severe flooding as an additional rationale for more riparian area to store flood water and to mitigate against damage. The agricultural landowners $(A g r)$ want less setback regulation so they can retain the option to sell valuable riverfront parcels and marginal agricultural lands. However, if there is frequent or severe flooding, agriculturalists will advocate for a larger setback preference to protect productive agricultural lands from flooding.

\subsection{Decision Outcome: Setback Ordinance Effects on Stakeholder Groups' Total Capital}

The Setback decision impacts the affiliative and economic capitals of all stakeholders. Because the outcome ultimately favors one group's setback preference, the "winning" group that benefits most from the decision sees their economic capital earning potential increase. The winning group's affiliative capital — their political clout—also increases within the decision-making setting. Once a setback decision is made, the winning stakeholder group whose preferred setback distance was selected (winner) earns 5 affiliative capital units because their preference proved socially acceptable (Table 5). The winning stakeholder group also earns a specific amount of economic capital (Table 6) as a result of the decision. Those stakeholder populations whose preferences were not selected are negatively affected by the decision outcome. They lose 5 
affiliative capital points (Table 5) and economic capital points (Table 7) because of the impact upon their earning potentials and political clout respectively. Each round of decision making has the potential to alter the total capital arrangements. The decision outcome cannot affect a stakeholder groups' levels of cultural capital, as heritage increases only by generation, and this credentialing occurs independently of changes in natural capital.

For the most part, the model is designed to mimic real-world scenarios of "the rich get richer" where those groups with a majority of accumulated capital continue to increase capital in the model structure at a greater rate than those with less total capital. Extenuating stochastic factors (Ran) may influence this structure representing dramatic changes such as severe flooding events or changes in state or federal policies that trump this local planning venue. Each positive impact upon stakeholder groups' capital reaches a maximum level of improvement (Table 5).

Table 5. Impacts of receiving setback preference on political clout

\begin{tabular}{|cccccc|}
\hline Social Capital & Effects of Receiving & $\frac{\text { Max Aff }}{\text { Improvements }}$ & & Effects of Not Receiving & Max Aff \\
\hline Aff Inv & Increference & $\underline{\text { pts }}$ & & Preference & $\frac{\text { pts }}{2}$ \\
\hline Aff Agr & Increased Political Clout & 5 & & Decreased Political Clout & 5 \\
\hline Aff Rec & Increased Political Clout & 5 & 5 & Decreased Political Clout & 5 \\
\hline
\end{tabular}

Table 6. Impacts and rationale for economic improvements due to increased native vegetation

\begin{tabular}{|c|c|c|}
\hline $\begin{array}{l}\text { Economic } \\
\text { Capital } \\
\text { Improvement }\end{array}$ & Effects of Increased Percent Riparian Area: Justification of weights & $\begin{array}{lll}\text { Max } & \text { Eco } & \text { pts@@ } \\
100 \% & \text { Riparian } \\
\text { Area } & \\
\end{array}$ \\
\hline Eco Rec & $\begin{array}{l}\text { - Improved aesthetic and scenic quality of the river } \\
\text { - Increased recreational opportunities for personal and business uses } \\
\text { - Suitable aquatic habitat for fish prey species and fish } \\
\text { - Woody debris and leaf litter input for habitat diversity for invertebrates } \\
\text { and fish } \\
\text { - Increased shade maintains suitable stream temperature for game } \\
\text { species spawning while lowering potential fishing restrictions due to } \\
\text { high water temperatures } \\
\text { - Increased shade also reduces algae growth which improves quality of } \\
\text { fishing experience and increases dissolved oxygen for game species } \\
\text { - Enhanced bottomland and upland terrestrial species diversity due to } \\
\text { suitable habitat, cover, and connectivity thus improving bird-watching, } \\
\text { wildlife viewing, and hunting opportunities } \\
\text { - Improved native vegetation cover enhances privacy for fishing, } \\
\text { boating, and hiking } \\
\text { - Improved bank stability due to vegetation rooting reduces turbidity } \\
\text { and provides underwater refuge for aquatic species during flooding } \\
\text { - Improved native vegetative cover also increases water quality by } \\
\text { filtering contaminants from residential and commercial sources which } \\
\text { negatively impact groundwater and aquatic habitat suitability }\end{array}$ & 30 \\
\hline Eco Agr & $\begin{array}{l}\text { - Improving quality and diversity of forage for livestock grazing } \\
\text { - Improving bank stability and reduces loss of land due to erosion } \\
\text { - Improving a sense of certainty from erosion losses } \\
\text { - Reducing exotic weed species management costs and time } \\
\text { - Increasing bottomland and upland terrestrial species diversity via } \\
\text { enhancing suitable habitat, cover, and connectivity thus improving } \\
\text { hunting lease opportunities }\end{array}$ & 20 \\
\hline Eco Inv & $\begin{array}{l}\text { - Improved aesthetic and biological quality of the river }=\text { improved } \\
\text { property value }\end{array}$ & 0 \\
\hline
\end{tabular}


At 100\% Riparian Area, the maximum economic capital an Agriculturalist earns is 20 points. At 100\% Riparian Area, the maximum economic capital a Recreationalist earns is 30 points. Even at 100\% Riparian Area, the Investment Landowner gains no economic capital because the losses of economic freedom greatly outweigh any gains in aesthetic value.

Table 7. Impacts and rationale for economic improvements due to decreased native vegetation

\begin{tabular}{|l|l|c|}
\hline $\begin{array}{l}\text { Economic } \\
\text { Improvements }\end{array}$ & $\begin{array}{l}\text { Effects of Decreased Percent Riparian Area: } \\
\text { Justification of weights }\end{array}$ & $\begin{array}{c}\text { Max Eco pts @, 0\% } \\
\text { Riparian Area }\end{array}$ \\
\hline Eco Inv & $\begin{array}{l}\text { - Improved access to developable areas } \\
\text { - Improved ability to subdivide parcels }\end{array}$ & 30 \\
\hline Eco Agr & $\begin{array}{l}\text { - Improved freedom to subdivide parcels and } \\
\text { develop land }\end{array}$ & 20 \\
\hline Eco Rec & $\bullet$ Loss of quality of recreational experience & -5 \\
\hline
\end{tabular}

At $0 \%$ Riparian Area, the maximum economic capital an Investment Landowner earns is 30 points.

At $0 \%$ Riparian Area, the maximum economic capital an Agriculturalist earns is 20 points.

At $0 \%$ Riparian Area, the Recreationalist loses 5 economic capital points.

Table 8. Catalysts for initiating decision-making process by stakeholder population

\begin{tabular}{|c|c|c|c|c|}
\hline \multicolumn{5}{|c|}{ Setback Preference in various catalyzing conditions: } \\
\hline & Infrequent Flooding & Frequent flooding & Severity of flood low & Severity of flood high \\
\hline INV & - & 0 & - & 0 \\
\hline REC & + & + & + & + \\
\hline AGR & - & + & - & + \\
\hline
\end{tabular}

$-=$ less setback preference

$+=$ more setback preference

$0=$ no resistance or advocacy

The Setback decision has an instant social impact and a delayed ecological impact through either an immediate increase $(R A i n)$ or decrease $(R A$ out $)$ in functional Riparian area; that change in natural capital as result of the setback outcome feeds back to a recalculation of social impact in the next time step. The Setback decision's impact upon affiliative capital is immediate. The winners win (setback favors preference) and the losers lose (setback does not favor preference) affiliative power to influence the decision-making group. Therefore, impact on economic capital is also instantaneous in that the freedom to legally use or sell space along the river is permitted or prohibited after the setback decision is made. The various setback decisions also influence the riparian area.

\section{Discussion}

To make environmental decisions, requires fashioning an imagined or mental model of the system from which to deliberate about consequences of possible options (Jones, Ross, Lynam, Perez, \& Leitch, 2011). In groups, these shared mental models become cultural models formed discursively evidenced by multiple forms of data, story, experience, etc. (Paolisso, 2002). When scientific experts are invited to develop technical representations of these systems familiar to residential decision makers, the realities of socio-political forces such as social influence and the uses of various forms of power should be considered if the model is to be a useful tool for decision making. An unrealistic or idealized representation of a familiar system will be dismissed as lacking salience, credibility, and legitimacy with local audiences of decision makers. Where 
technically-trained experts evaluate models based on the adherence to biophysical rules, nontechnical audiences evaluate models based the presence or absence of components that reflect their personal experiences and tacit knowledge of the represented system (Hall et al. 2014). For models to serve as effective boundary objects that enable the integration of system assumptions and facilitate decision making, they must be meaningful to audiences expected to implement the decisions.

Bourdieu's forms of capital offer one means of representing non-material forms of wealth, cultural, and social affiliation which act as forms of influence within politics of shared resource decision making. Representing power and influence in terms of material capital enables modelers a form of currency to illustrate the impact of human capital on natural capital (ecological services/functioning). Further, the commensurate language of capital allows models to display a hypothetical policy's influence on the accumulation of types of capital among social players and ecological systems.

We hope others find this medium of capital useful in constructing more nuanced social-ecological models to illustrate interactions with greater sophistication. As tools that bridge differing communities engaged in a working relationship, boundary objects, like models, permit the rules of authoring agencies to be bent if it suits the needs of the partnership (Guston, 2001). Successful integration of different ways of knowing into models may require breaking some established norms.

\section{Conclusion}

In this essay, we constructed a conceptual model that used the social theory of various forms of social capital articulated by Bourdieu to make explicit the subtleties of influence that occur within rural communities on the Yellowstone River in park County, MT, USA. We used largely qualitative data from face-to-face ethnographic interviews to structure this model. Our next steps are to build a mathematical model and to run the model with an audience of Park County Montanans to solicit feedback on the salience of the model. The aim is to develop a model that is a realistic representation of the relatively obdurate biophysical and socio-political facts of the valley that any agile decision making must navigate.

Natural resource management agencies must balance the risks of losses in natural capital and losses in public support. This modelling approach could guide agents through the anticipation of scenarios likely to occur as publics respond to agency decisions, which lead to an ecological response that, in turn, influences future public response. A model that incorporates more sophisticated socio-political factors, like locally known realities of power and influence, may explain how seeming small decisions made by agencies may yield large responses in both public satisfaction and ecosystem function over time.

\section{Acknowledgements}

People of Yellowstone River, Montana, USA; US Army Corps of Engineers-Omaha District; Yellowstone River Conservation District Council; Bill E. Grant; Montana State UniversityBillings.

\section{References}

Allen, T.F.H., Zellmer, A.J., \& Wuennenbeg, C.J. (2005). The loss of narrative. In K. Cuddington \& B.E. Beisner, (Eds.), Ecological paradigms lost: Routes to theory change. Theoretical ecology series (pp. 333-370). New York: Academic Press. 
American Rivers and Greater Yellowstone Coalition. (2003). Implementing a common sense floodplain development policy along the Yellowstone River: Park County. (pp 1-18) Retrieved at http://www.greateryellowstone.org/pdf/parkcounty.pdf

Ascough II, J. C., Maier, H.R., Ravalico, J.K. \& Strudley, M.W. (2008). Future research challenges for incorporation of uncertainty in environmental and ecological decision making. Ecological Modelling, 19, 383-399.

BBC Research \& Consulting. (2002). Socioeconomic assessment of the upper Yellowstone River. Denver, Colorado: BBC Research \& Consulting.

Bourdieu, P. (1985). The social space and the genesis of groups. Theory and Society, 14, 723-744.

Bourdieu, P. (1986). The forms of capital. In J.G. Richardson (Eds.), Handbook of theory and research for the sociology of education (pp. 241-258). New York: Greenwood Press.

Bourdieu, P. (1989). Social space and symbolic power. Sociological Theory, 7, 14-25.

Bourdieu, P. (1990). Logic of practice. Stanford, California: Stanford University Press.

Bourdieu, P. (1993). Language and symbolic power. (Gino Raymond \& Matthew Adamson, Trans.). Cambridge, MA: Harvard University Press. (Original work published 1991)

Bousquet, F. \& Le Page C. (2004). Multi-agent simulations and ecosystem management: a review. Ecological Modelling, 176, 313-332.

Burke N.J., Joseph G., Pasick R.J., \& Barker, J.C. (2009). Theorizing social context: rethinking behavioral theory. Health Educ. Behav. 36:55S-70

Cash, D.W., Borck, J.C., \& Patt, A.G. (2006). Countering the loading-dock approach to linking science and decision making. Sci. Technol. Hum. Val., 31, 465-495.

Cash, D. W., Clark W.C., Alcock, F., Dickson, N.M., Eckley, N., Guston, D.H... \& R. B. Mitchell. (2003). Knowledge systems for sustainable development. Proceedings of the National Academy of Sciences of the United States of America, 100(14), 8086-8091.

Chapple, S. (1997). The Yellowstone: the last best river. National Geographic, 194(4), 56-77.

Clark, W.C. (2007). Sustainability science: A room of its own. P. Natl. Acad. Sci. US A, 104, 1737-1738.

Clark, W.C., Tomich, T.P., van Noordwijk, M., Guston, D., Catacutan, D., Dickson, N.M., \& McNie, E. (2011). Boundary work for sustainable development: natural resource management at the Consultative Group on International Agricultural Research (CGIAR). P. Natl. Acad. Sci. USA, published ahead of print August 15, 2011, doi:10.1073/pnas.0900231108.

Costanza, R. \& Daly, H.E. (1992). Natural capital and sustainable development. Conservation Biology, 6, 37-46.

Courtois, P. \& Tazdait, T. (2007). Games of influence in climate change negotiations: modelling interactions. Ecological Modelling, 204, 301-314.

Crane, T. A. (2010). Of models and meanings: cultural resilience in social-ecological systems. Ecology and Society, 15(4), 1-19.

Dietrich, W.E., Bellugi, D.G., Sklar, L.S., \& Stock, J.D. (2003). Geomorphic transport laws for predicting landscape form and dynamics. Prediction in Geomorphology Geophysical Monographs, 135, 1-30.

Dryzek, J. S. (1997). The politics of the earth. New York: Oxford University Press.

Ellis, J. H. \& Richard, J. (2008). A planning guide for protecting Montana's wetlands and riparian areas. Montana Watercourse publication. Retrieved at www.mtwatercourse.org

Gibbons, M. (1999). Science's new social contract with society. Nature, 402, C81-84.

Gibbons, M. (2000). Context-sensitive science: Mode 2 society and the emergence of context-sensitive science. Science and Public Policy, 27, 159-163.

Gilbertz, S., Austin, E.A., Norton, J., Horton, C., \& Hall, D.M. (2011). Wicked wisdoms: Illuminations of conceptual capacities among local leaders of the Yellowstone River. Studies in Sociology of Science, 2(2).

Gilbertz, S., Horton, C.C. \& Hall, D.M. (2007). The Greater Yellowstone River Cultural Inventory. Corps of Engineers Technical report. Retrieved at http://www.yellowstonerivercouncil.org/dev/resources.php

Governor's Upper Yellowstone River Task Force (Montana). (2003). Governor's Upper Yellowstone River Task Force final report. Retrieved at https://archive.org/details/A521E336-CCFF-49F9-9CBA77B624F63F97

Grant, W.E. (1998). Ecology and natural resource management: reflections from a systems perspective. Ecol. Mod., 108, 67-76.

Greater Yellowstone Coalition (2002). Tempting Fate. Retrieved at www.greateryellowstonecoaltion.org. 
Guston, D.H. (2001). Boundary Organizations in Environmental Policy and Science: An introduction. Sci. Tech. Hum. Val. 26, 405.

Hall, D.M. (2006). Common sense fieldwork on the Yellowstone River. Rocky Mountain Communication Review, 3(1), 89-95.

Hall, D.M., Gilbertz, S., Horton, C., \& Peterson, T.R. (2012). Culture as a means to contextualize policy. Journal of Environmental Studies and Sciences, 2(3), 222-233.

Hall, D.M., Gilbertz, S., Horton, C., \& Peterson, T.R. (2013). Integrating divergent representations of place into decision contexts. In W.P. Stewart, D. R. Williams, \& L. E. Kruger (Eds.). Place-based Conservation: Perspectives from the social sciences (pp. 121-136). Dordrecht: Springer Press.

Hall, D.M., Lazarus, E.D., \& Swannack, T.S. (2014). Strategies for communicating systems models. Environmental Modelling \& Software, 55, 70-76.

Hall, D. M., Silka, L., \& Lindenfeld, L. (2012). Advancing science and improving quality of place: Linking knowledge with action in Maine's Sustainability Solutions Initiative. Maine Policy Review, 21(1), 2229.

Heemskerk, M., Wilson, K., \& Pavao-Zuckerman, M. (2003). Conceptual models as tools for communication across disciplines. Conserv. Ecol., 7, 8.

Honadle, G. (1999). How context matters: Linking environmental policy to people and place. West Hartford, CT: Kumarian Press.

Jasanoff, S. (1990). The fifth branch: Science advisors as policy makers. Cambridge, MA: Harvard University Press.

Jones, N.A., Ross, H., Lynam, T. Perez, P. \& Leitch, A. (2011) Mental models: an interdisciplinary synthesis of theory and methods. Ecology and Society, 16(1).

Kates, R.W. (2011). What kind of a science is sustainability science? P. Natl. Acad. Sci. USA., 108, 1944919450.

Kates, R.W., Clark, W.C., Corell, R., Hall, J.M., Jaeger, C.C., Lowe, I... Svedin, U. (2001). Sustainability science. Science, 292(5517), 641-642.

Kemmis, D. (1990). Community and the politics of place. Norman, OK: University of Oklahoma Press.

Krebs, C. J. (2000). Hypothesis testing in ecology. In L. Boitani and T. K. Fuller (Eds). Research techniques in animal ecology (pp. 1-14). New York: Columbia University Press.

Latour, B. (1999). Politics of nature: how to bring the sciences into democracy (C. Porter, Trans.). Harvard University Press, Cambridge, MA. (Original work published 2004)

Leighton, K. (1998). Great American rivers: Seasons of the Yellowstone an angler's year. Minocqua, WI: Willow Creek.

Levrel, H., Etienne, M., Kerbiriou, C., Le Page, C., \& Rouan, M. (2009). Co-Modeling process, negotiations, and power relationships: some outputs from a MAB project on the Island of Ouessant. Society and Natural Resources, 22, 172-188.

Lincoln, Y. S., \& Guba, E.G. (1985). Naturalistic inquiry. Newbury Park, CA: Sage.

Lowery, C. (2009, March 16). Measure to regulate development along Montana rivers likely dead. New West. Retrieved at http://newwest.net/topic/article/bill_that_would_have_created_streamside_setbacks_on_ montana_rivers_likely_d/C37/L37/

Lucie, R., L. Gauvin, \& K. Raine. (2011). Ecological Models Revisited: Their Uses and Evolution in Health Promotion Over Two Decades. Annual Review of Public Health. 32, 307-326.

Manor, J. (1999). The political economy of democratic decentralization. Washington, DC: The World Bank.

Mitsch, W. J. \& Gosselink, J.G. (2007). Wetlands. Hoboken, NJ: John Wiley \& Sons.

Montana Council of Trout Unlimited, et al., v. US Army Corps of Engineers, et al., Vol. 76, p. 3199 (United States District Court, District of Montana, May 11, 2000).

Naiman, R. J. \& Decamps, H. (1997). The ecology of interfaces: Riparian zones. Annual Review of Ecology and Systematics, 28, 621-658.

Nolt, D. (2007, April 7). Free river: How the Yellowstone River kept its course. New West. Retrieved at http://www.newwest.net/city/article/free_river_how_the_yellowstone_river_kept_its_course/C396/L396/

Odum, H. T. (2007). Environment, power, and society for the Twenty-First Century. New York: Columbia University Press.

Paolisso, M. (2002). Blue crabs and controversy on the Chesapeake Bay: a cultural model for understanding watermen's reasoning about blue crab management. Hum. Organ., 61, 226-239.

Big Sky Hazard Management. (2005). Park County, MT Hazard Mitigation Plan. 
Peterson, M. J., Peterson, M. N., \& Peterson, T. R. (2005). Embracing the Paradoxical in Environmental Decision-Making. In G.B. Walker \& W.J. Kinsella (Eds.). Finding our ways(s) in Environmental Communication: Proceedings of the Seventh Biennial Conference on Communication and the Environment, (5261).

Peterson, M.N., \& Liu, J.G. (2008). Property rights and landscape planning in the intermountain west: The Teton Valley case. Landscape and Urban Planning, 86 (2), 126-133.

Peterson, M. N., Peterson, M.J., \& Peterson, T.R. (2005). Conservation and the myth of Consensus. Conservation Biology, 19, 762-767.

Pohl, C. (2011). What is progress in transdisciplinary research? Futures, 43(6), 618-626.

Raik, D. B., Wilson, A.L. \& Decker, D.J. (2008). Power in natural resources management: an application of theory. Society \& Natural Resources, 21: 729-739.

Robbins, P. (2012). Political ecology: a critical introduction. (2nd ed.). West Sussex, UK: Wiley-Blackwell.

Robinson, J. B. (1991). Modelling the interactions between human and natural systems. International Social Science Journal, 130, 629-647.

Salzman, J., \& Thompson, Jr., B.H. (2014). Environmental law and policy. New York, NY: Foundation Press.

Sandström, C. (2009). Institutional dimensions of comanagement: participation, power, and process. Society \& Natural Resources, 22, 230-244.

Schmolke, A., Thorbek, P., DeAngelis, D.L., \& Grimm, V. (2010). Ecological models supporting environmental decision making: a strategy for the future. Trends Ecol. Evol., 25, 479-486.

Star, S.L., \& Griesemer, J.R. (1989). Institutional Ecology, Translations' and Boundary Objects: Amateurs and Professionals in Berkeley's Museum of Vertebrate Zoology, 1907-39, Soc. Stud. Sci., 19, 393.

Tabacchi, E., \& Planty-Tabacchi, A. (2005). Exotic and native plant community distributions within complex riparian landscapes: A positive correlation. Ecoscience, 12, 412-423.

Talwar, S., Wiek, A., \& Robinson, J. (2011). User engagement in sustainability research. Sci. Public Pol., 38(5), 379-390.

Thatcher, T., Swindell, B.S., \& Boyd, K. (2009). Yellowstone River channel migration zone mapping. Prepared for: Yellowstone River Conservation District Council.

U.S. Geological Survey, Biological Resources Discipline. (2004). Summary of studies supporting cumulative effects analysis of upper Yellowstone River channel modifications (Open File Report 2004-1442). Reston, VA: U.S. Geological Survey.

van den Belt, M. (2004). Mediated modeling: A system dynamics approach to environmental consensus building. Washington, D.C.: Island Press

van der Leeuw, S.E. (2004). Why model? Cybernet. Syst., 36, 117-128.

Voinov, A., \& Bousquet, F. (2010). Modelling with stakeholders. Environ. Modell. Softw., 25, 1268-1281.

Voinov, A., Seppelt, R., Reis, S., Nabel, J. E.M.S., \& Shokravi, S. (2014). Values in socio-environmental modelling: persuasion for action or excuse for inaction. Environ. Modell. Softw., 53, 207-212.

Ward, J. V., K. Tockner, \& F. Schiemer. 1999. Biodiversity of floodplain river ecosystems: ecotones and connectivity. Regulated Rivers: Research and Management 15, 125-139. 